Page I - 28

\title{
BANKING COMPETITION MEASUREMENT AND BANKING SECTOR PERFORMANCE: ANALYSIS OF 4 ASEAN COUNTRIES
}

\author{
Buddi Wibowo \\ Universitas Indonesia \\ buddi.wibowo@ui.ac.id
}

\begin{abstract}
Many believe concentrated banking industry which is dominated by few big banks creates lower competition, high profitability, and low efficiency. The main issue in empirical testing of this hypothesis is how to measure banking competition level. Traditional measures of competition are concentration ratio and Herfindahl-Hirschman Index. This study uses three measures of banking level competition which are widely used in recent financial literature: Boone Indicator, Lerner Index and H-Panzar-Rosse statistics. Lerner Index and H-Panzar-Rosse statistics resulted a similar competition level conclusion, while Boone Indicator produced slightly different output. Industry concentration produced opposing results with those three level of industry competition measurement methods. The results show banking competition tend to be a monopolistic competition in ASEAN countries, especially in Indonesia which banks' strategy basically were non-pricing strategy. Competition significantly caused lower profitability, while banking efficiency weas not significantly affected by level of competition.
\end{abstract}

Keywords: banking, concentration, competition, efficiency, profitability

\begin{abstract}
Abstrak
Banyak orang percaya industri perbankan yang didominasi oleh beberapa bank besar akan menciptakan kompetisi yang lebih rendah, profitabilitas yang tinggi, dan efisiensi yang rendah. Isu utama dalam pengujian empiris hipotesis seperti ini adalah bagaimana mengukur tingkat kompetisi perbankan. Metode tradisional dalam mengukur tingkat persaingan antara lain rasio konsentrasi dan Herfindahl-Hirschman Index. Penelitian ini menggunakan tiga langkah kompetisi tingkat perbankan yang banyak digunakan dalam literatur keuangan baru-baru ini: Boone Indicator, Lerner Index dan statistik H-Panzar-Rosse. Lerner Index dan H-Panzar-Rosse statistik menghasilkan kesimpulan tingkat kompetisi yang sama, sementara Boone Indikator output yang dihasilkan sedikit berbeda. konsentrasi industri menghasilkan hasil yang berlawanan dengan tiga tingkat metode pengukuran persaingan industri. Hasil penelitian menunjukkan persaingan perbankan cenderung menjadi persaingan monopolistik di negara-negara ASEAN, esspecially di Indonesia dimana bank strategi pada dasarnya adalah strategi non-harga. Kompetisi secara signifikan menyebabkan profitabilitas yang lebih rendah, sementara efisiensi perbankan tidak signifikan dipengaruhi oleh tingkat persaingan.
\end{abstract}

Kata Kunci: perbankan, konsentrasi, persaingan, efisiensi, profitabilitas

Received: January 3, 2017; Revised: January 30, 2017; Approved: February 28, 2017 
Banking Competition Measurement...

Buddi Wibowo

\section{INTRODUCTION}

Banking competition not only impacts banks' performance, but also affects the real sector (Carbó, et al, 2009), economic growth (Collender and Shaffer, 2003), financial system stability (Cihak, et.al, 2006) and monetary policy effectiveness launched by the central bank (De Jonghe and Vennet, 2008). Competition in the banking industry drives bank loan interest rate which is a major real sector investment driver and affect private consumption. Investment and consumption are important determinant of a country's economic growth. Central bank monetary policy transmission also can take place smoothly and in a relatively short time lag if banking competition is quite tight. More tighter competition among banks, the faster banks response to the benchmark interest rate changes and other monetary policy released by central banks so that both monetary policy and fiscal policy can be an effective policy and mutually supportive.

The simplest industry competition measurement is the Concentration Ratio which is the percentage of revenues, profits or third party funds in the banking sector dominated by several large banks. For example, Revenue CR3 is the concentration ratio which indicates the percentage of three biggest companies in the industry total revenue to total industry revenue, while CR5 shows the dominance of the five largest banks in the banking industry. Some experts claim that the Concentration Ratio can result an erroneous conclusion about industry competition level because it ignores the distribution of market share among all the companies that exist in an industry (e.g Apergis, et.al, (2016); Berger, et.al (2004)). A industry with high CR3 does not necessarily mean low industry competition because competition among the rest of companies (all companies excluding the three biggest companies) may be very tight. Focusing only on market domination by some of biggest companies and ignoring the competitive dynamics of other companies that exist in an industry may drive to wrong conclusion about industry competition level. Considering weakness of this measure, some experts encourage the use of a measure of concentration called the HerfindahlHirschman Index. Herfindahl-Hirschman Index $(\mathrm{HHI})$ is a measure of the level of concentration based on the distribution of market share of all companies that exist in an industry. 
Industry concentration is actually a proxy variable that was widely used by researchers to measure industry level of competition. Some empirical research show the concentration ratio of banking industry does not accurately reflect competition of the banking industry (Berger, et al. (2004); Claessens and Laeven (2004)). When an industry concentration is high, it does not necessarily mean low competition level. On the other hand low concentration does not necessarily mean a very tight competition also. This empirical measurement problem encourages researchers to develop more reliable empirical competition level measurement method (Bikker, et.al (20I2); Maudos and Solis (20II).

To obtain a robust measure of banking industry competition, this paper uses three competition measurements which currently are getting wide acceptance in academic community and among practitioners also. These three competition measures came from the New Empirical Industrial Organization stream of research which proposed methodologies of competition measurement with a solid economics foundation. These three competition measurement are Boone indicator, Lerner index, and Panzar-Rosse $\mathrm{H}$-statistics. Each measurement provides a sligthly different information of the existing competition in an industry, eventhough they has a similar approach to measure how intense the competition is. All these competition measures lay their argument on microeconomics theory of market behavior, how market power obtained by a producer drives his behavior in setting up price of his product or services. However each indicator reflects different aspect of the competition (Degryse et al., 2009).

Boone (2008) built a banking competition indicator based on a basic idea that the efficient firms will benefit more in a competitive market. More efficient the company, more superior their performance compared to competitors so they can accumulate greater profits than their rival. When competition becomes tighter, efficient firms can exploit their cost superiority to be an effective tool to grasp bigger market size and profit. Boone indicator as a measure of competition has been quite widely used in banking research (eg Delis, 20I2; Tabak et al., 2012; Schaeck, et.al, 2013). Boone Indicator is a measure of banking competition based on the pattern of profit-efficiency relationship. Boone indicator reflects the elasticity of bank's earnings to changes of bank's marginal costs. The increasing value of Boone indicator indicates a 
Banking Competition Measurement...

Buddi Wibowo

worsening of the competitive behavior (competitive conduct) of this financial intermediary institution. To obtain Boone Indicator, we could take a regression of income logarithm (measured by ROA, return on assets) against the logarithm of marginal costs. The regression produces an estimated coefficient which show elasticity between those two variables. Financial intuition behind the Boone indicator is higher profits will be obtained only by more efficient bank. Boone indicator is in a negative number, so more lower the Boone indicator, the higher the level of an industry competition. Boone indicator estimation procedure used in this study follows the methodology proposed by Schaeck, et.al (2010).

Boone indicator has two advantages. Firstly, Boone Indicator has very strong theoretical basis. Boone Indicator is built on solid microeconomics theory and based on two assumptions: restricted entry barriers and the aggressiveness of existing companies in an industry. Secondly, Boone indicator can capture both the dynamics of competition and non-price strategy in the market compared to other competition measures which are only based on price competition and static state of competition (Schaeck, et.al (2010)). However, Boone indicator has a weakness, because of its emphasis on the dynamics of competition, it assumes firms are always able to immediately transform benefits from the efficiency advantages into a higher income and profit. Though in the short term usually benefits from such efficiencies are not always evident in earnings or profit, but they can produce other performance superiority such as consumer satisfaction and loyalty or bigger market shares (Leon, 20I5).

To get a comprehensive banking competition measures, this study also uses two non-structural competition measurements besides Boone Indicator, Lerner index and $\mathrm{H}$ Statistic Panzar-Rosse. Lerner index measures each bank's degree of competitiveness. Lerner Index measures bank ability to keep its product prices always above marginal cost. The marginal cost of each bank is obtained by estimating the bank cost function with three input factors, which are the cost of labor, physical capital costs, and cost of funds. Boone (2008) shows the Lerner index at the country level consistently produced over estimated competition level because it is affected by how aggressive existing companies behave and bank margin costs are also sensitive to macroeconomic conditions (Carbó et al., 2009). However, Demirguc-Kunt and Peria (2010) demonstrated the superiority of the Lerner index compared to the Panzar- 
Rosse $\mathrm{H}$ statistic. Because the Lerner Index is not a measure of competition in long term equilibrium as Panzar Rosse $\mathrm{H}$ statistics so that the Lerner Index can be calculated for the shorter period of observation. Lerner Index show short term dynamic of competition.

Panzar and Rosse (1987) developed a competition measurement model by estimating how much the difference of average price set up by existing companies in the industry compared to the pricing strategy of a perfectly competitive market (Bikker, et.al, 2012). The company's response to changes of input prices and how they transform it into product price depend on the competitive behavior of all market participants in the industry. Competition level is measured by examining how strong the effect of input price changes are reflected in the companies' revenue equilibrium. In a perfect competition market, for example, changes of input prices can not be transferred into higher selling prices because all sellers and producers simply are price takers. The company's revenues are very influenced by changes in production input prices in such market where declining input prices will encourage producers to increase the number of output in some extent to capture the opportunity to gain higher profit. Declining input prices drive a increase of total revenue in same proportion. Conversely when input prices rise, the total income of the company will decrease proportionally also because the average company will reduce the amount of output so that total revenue will decrease proportionately. The relationship between input prices with the company's revenues becomes very elastic (unity elasticity).

Panzar-Rosse competition model produce competition level indicator known as the $\mathrm{H}$-statistic, where the $\mathrm{H}$-statistic became a quantitative measure of intra-industry competition level. $\mathrm{H}$-statistic generated from Panzar-Rosse competition model shows the elasticity of total revenue to changes of input prices. H-statistic measures how much a change in input prices are reflected in the income received by all companies on average. In the case of perfect competition market, a rise of input prices will cause a rise in marginal costs and total revenues at the same time. In a monopoly market, a rise of input prices will cause a rise in marginal costs and will encourage manufacturers to lower the amount of equilibrium output, so the total revenue will decrease. $\mathrm{H}$ statistic below zero indicates a monopoly or oligopoly type of competition where there is a collusive agreement among manufacturers to lower the amount of 
Banking Competition Measurement...

Buddi Wibowo

output. $\mathrm{H}$ statistics equals one gives an indication of perfect competition market. $\mathrm{H}$ statistics between one and zero indicates a monopolistic competition where the company may face a tough competition in the industry, but because every company has their own market segments so each company can behave as a monopoly in the market segments it serves.

Panzar-Rosse model is a reduced-form models of the bank total income with bank input prices as explanatory variables and some banks characteristics as control variables. The regression coefficients estimated by Panzar-Rosse model are actually elasticity of total revenue response to input price changes. $\mathrm{H}$-statistic is the sum of all coefficients contained in the Panzar-Rosse model. Almost all empirical test show banking competition in developed countries, using Panzar-Rosse $\mathrm{H}$ statistics as competition measures, mimicked a monopolistic competition market (Apergis, et.al, 2016). In monopolistic competition, companies compete with each other but each company has a specific product and market segments which are quite separately so that the increase of input prices can partly be transferred into price increases, and total output does not drop too much. Demand is not too sensitive to the increase of selling prices in monopolistic competition because every market segments are loyal to a specific bank or, in other words, every bank has relatively strong market power in the market segments it serves. If regression coefficients in Panzar-Rosse model is between zero and one, which is an indication of monopolistic competition market, then it indicates an increase in input prices led total revenue to rise but revenue increase percentage is lower than the input price increase percentage. On the other hand, if input prices decrease, total revenue does not decrease because input prices does not lead to lower price. In monopolistic competition market, lower selling price does not necessarily induce higher total demand in each bank's market segment. Meanwhile, selling price of other companies also do not affect this market segments demand. Bank tend to play a non price strategy in the monopolistic competition market.

Bikker and Haaf (2000) examined competition of the banking sectors in the 23 countries using Panzar-Rosse (1987) approach. Their results showed that majority of banking industries in the world can be categorized as a monopolistic competition market. Small banks, on average, operated in a less stringent market and served 
specific market segments compared to larger banks. Large banks and medium banks both generally served almost same market segments so that the competition among large and medium banks became relatively far more stringent than competition among small banks. Bikker and Spierdijk (2008) with greater data consist of banking sectors from IOI countries, also using Panzar-Rosse approach, find majority of banking competitions in the world can be classified as a monopolistic competition market. European banking competition level has decreased significantly. But on the other hand, banking industry in developing countries have a tendency to become more competitive.

The relationship between banking competition, efficiency and profitability is still a topic of academic debate. Bikker and Spierdijk (2008) stated that the competition encourages banks to minimize costs so that it can sell services at a cheaper price and make higher profit. Banks which are efficiently managed will beat inefficient banks and are able to foster consistent profits so that its assets and its market share continues to grow. The concentration of the industry would be even higher in the banking industry with a high degree of competition (De Jonghe and Vennet, 2008). Contrary, low competition level will drive bank managers enjoy what is called as a "quiet life" where operational cost is not adequately controlled and efficiency levels are low but profitability remains at high level persistently (Dietrich and Wanzenreid, 201 I; Berger and Hannan, 1998),

Chen and Liao (20II) construct a theoretical model that show banks at a competitive banking sector will be encouraged to have a better procedure for selecting and monitoring customers, so bad loans tend to be relatively lower. Customers who have a better risk profile will select bank which owns best selection and monitoring procedures because these bank are able to distinguish and measure the credit risk of each customer accurately so that the pricing of bank loans is based on accurate each customer's risk level. Customers with large credit risk tend to avoid to propose a loan to this type of bank and prefer banks which have weaker and relatively inaccurate credit assessment procedure so there is a opportunity to obtain more favorable credit pricing due to bank's negligence. As a result, banks which have better procedures for selecting customer and better credit risk assessment will have better portfolio of credit, lower non performing loan, and better cost efficiency than banks which do not 
Banking Competition Measurement...

Buddi Wibowo

have such procedure. Typically small banks do not have complete procedure and thorough credit risk assessment techniques. Small bank tends to have worst credit portfolio. Small banks become less efficient and become an acquisition target or forced to be merged or exit the market. Based on this conceptual framework, the competitive banking industry tend to become more concentrated and dominated by few large banks.

Some experts have hypothesized relationship between competition and efficiency of the banking industry in opposing position from above hypothesis. Competition actually drives to lower bank efficiency. They argue that high competition will cause fragile and short term-minded customer-bank relation (Maudos and Solis, 20II). Customers tend to easily switch to another bank in an intense banking competition. Bank's credit market becomes a highly asymmetric information market so bank requires an additional costs to attract customers, to monitor a loan and to educate customers. Bank's total cost will increase and eventually be transferred into higher interest rate and service fees. This argument underlies the alleged negative relationship between banking competition level and banking sector efficiency because banks need to spend more to create and maintain their competitiveness in a competitive market. When competition become tighter, competition among banks no longer centered on the interest rate offered by each bank but rather on providing more comprehensive services and better facilities for business customers (non-price competition). De Jonghe and Vennet (2008); Chen and Liao (20II) show that there were an inverse relationship between competition and efficiency of the bank in some countries.

This study measures the concentration of four ASEAN country banking industries and their level of competition also. Two industry concentration measures which are Concentration Ratio and the Herfindahl-Hirschmann Index $(\mathrm{HHI})$ were estimated and the results were compared. Three banking industry competition measure also were estimated to measure the banking competition level in those countries. Three indicators of the banking competition level were estimated so we are able to capture the different aspects of the competition. Lerner index measures the individual bank's market power to set up price in the market, assuming the price is fixed (static market power). Panzar-Rosse $\mathrm{H}$-statistic measure banking industry 
competition as speed of input prices transmission to bank income level. Boone indicator is a measure of competition that capture the market dynamics. Due to each measure show different aspects of the competition, those three competition measure may produce different result. This study compares all banking industry concentrations and competition measurements that exist in literature, so we can examine their similarity, strengths and weakness. Comparing their measuring performance in four different countries, we can also test their consistency amid different banking industry context and competitive dynamics. Four observed ASEAN countries, Indonesia, Thailand, Malaysia, and Phillipines have relatively similar stage of banking development, eventhough they have their own pace of advancement, efficiency, profitability and regulatory setting.

\section{METHOD}

The sample of this study are banking industries in Indonesia, Malaysia, Philippines, and Thailand. This study uses financial statements of all banks in Indonesia which actively operated in the period 2000 to 2013. Data from 1998 to 2010 were obtained from Bank Indonesia and data 2010 to 2013 were obtained from Indonesia Financial Services Authority. Banking industry data for other countries were obtained from Thomson Reuters, the World Bank, and the Central Bank in Malaysia, Thailand and Philippines.

\section{Measurement Method}

To measure the concentration of banking industry, this study uses two measures: concentration ratio and Herfindahl-Hirschman Index. Concentration Ratio is estimated with following formula:

$$
C R=\sum_{i=1}^{k} s i
$$

where CR is Concentration Ratio, $s_{i}$ is each bank's market share, $k$ is number of bank which operated in given period. Bank's market share is a ratio between bank's total asset and total asset of banking industry (Bikker dan Spierdijk, 2008). For robustness test, Concentration ratio, besides in bank's total asset value, were also measured in two different aspects: market share in credit market and third party deposits.

This study also uses two type of Concentration ratio, CR3 and CR5, which show market domination by three largest bank and fifth largest bank subsequently. High 
Banking Competition Measurement...

Buddi Wibowo

concentration ratio indicates highly concentrated structure of the industry, where large banks have a dominant market share and have a very strong market power. However, Concentration Ratio may produce an erroneous conclusions because it only measures the market share of the three (CR3) or five (CR5) largest companies in the industry and ignores how market share are distributed among the rest of banks that exist in the industry. Even distribution of the market share between the most biggest bank that are included in the three or the five biggest in CR3 dan CR5 can not be captured by concentration ratios. For an example, in a country its largest bank grasps $40 \%$ market share, while the two other largest companies both own $10 \%$ of the shares. On the other hand, another country which has three largest banks that each control $20 \%$ market share. Those two countries will have the same concentration ratio, CR3 will be exactly same, namely $60 \%$. To overcome this disadvantages of the concentration ratio, the author used also another banking industry concentration measure: Herfindahl-Hirschman Index $(\mathrm{HHI})$. $\mathrm{HHI}$ is calculated by using all market share of each bank in a country

$$
H H I=\sum_{i=0}^{N} s_{i}^{2}
$$

where $s^{2}$ is square of each bank's market share in a given period. $\mathrm{N}$ is number of banks. $\mathrm{HHI}$ may have value from $\mathrm{I} / \mathrm{N}$ to $\mathrm{I}$. An industry which has $\mathrm{HHI}=\mathrm{I} / \mathrm{N}$, has a perfect competitive market where each bank has equal market share. $\mathrm{HHI}=\mathrm{I}$ indicates a monopoly.

US Departement of Justice has a specific competition level category based on $\mathrm{HHI}$ : if $\mathrm{HHI}$ is lower than 0,15 than it indicates low industry concentration and high competition. If $\mathrm{HHI}$ is between 0.15 and 0.25 , it indicates a moderate concentration and competition level. If $\mathrm{HHI}$ is higher than 0.25 , it indicates highly concentrated industry and low competition level. (http://www.justice.gov/atr/herfindahl-hirschmanindex).

To measure banking competition, the study uses three approaches which are Boone Indicator, Lerner Index and Panzar-Rosse which were used by previous researchers such as Leon (20I5), Anginer et al, 20I2), Bikker, et.al (20I2), and Samad (2008). Panzar-Rosse approach is basically to model bank revenue function with the price of bank production factors as an independent variable. Panzar-Rosse approach 
assumes that the bank has three inputs in bank production process which are labor, deposits, and infrastructures. The price of bank production factors are: Average Funding Rate (AFR), the ratio of interest expense to total third party funds, Price of Personeel Expenses (PPE), which is the ratio of labor costs to total assets, and Price of Capital expenditure (PCE), which is the ratio of the physical assets cost and other expenditures cost on fixed assets. Banking competition level measures produced by Panzar-Rosse approach is $H$ statistics which is the sum of the three regression coefficients in the regression of bank revenue on three inputs prices of the bank production process. Besides bank input prices, reliable model should include some control variables. These control variables have a significant influence on bank revenues. These control variables usually called as Bank Specific Factors (BSF) such as bank size, bank capital structure, and bank risk.

First Bank Specific Factor is bank's total assets which is a proxy measure of bank's economic scales. Although there is still a debate in banking research literature whether larger bank is more likely to become an efficient bank, but almost all researchers agree that the size of the bank greatly affect the level of bank income (Barbosa, et.al 2015). The second control variable is the bank capital adequacy which can be captured through the ratio of total equity to total assets. Shaffer (2004) shows the capital ratios significantly affect bank's risk taking and bank's profitability. The structure of bank funding which is reflected in the ratio of total debt to total assets also determine the level of bank profitability. The greater proportion of bank loans in bank fundings, the bank will be more willing to take risk so that the profitability of banks will be higher, but on the other hand bank's risk level increases. Liquidity risk which is reflected in the bank cash ratio, total cash to total deposits, is a control variable used to control risk level in bank revenues. The last control variables is the proportion of bank's $o$ ther income in its total income.

Log-normal function reduced form model of bank revenue which is used to calculate Panzar-Rosse $\mathrm{H}$ statistic as a measure of banking industry competition level is:

Revenue $_{i}=\alpha+\beta A F R_{i}+\gamma P P E_{i}+\delta P C E_{i}+\lambda_{1} E Q+\lambda_{2} L O+\lambda_{3} C A S H+\lambda_{4} A S S E T+\varepsilon_{i}$ 
Banking Competition Measurement...

Buddi Wibowo

Where Revenue: logarithm of bank's total revenues, AFR = interest expense to total deposits ratio, $\mathrm{PPE}=$ Personeel expense to total employees, $\mathrm{PCE}=$ administrative and operational expenses to total asset, $E Q=$ total equity to total asset, $\mathrm{LO}=\mathrm{New}$ loan to total loan ratio, $\mathrm{CASH}=$ total cash to total deposits ratio.

Panzar-Rosse $\mathrm{H}$ statistics is calculated by formula:

$$
\mathrm{H} \text {-statistic }=\beta+\gamma+\delta
$$

We get $\beta, \gamma$, and $\delta$ by estimating model (3) for yearly data so we can get yearly banking competition level in each country. To classify banking competition level based on Panzar Rosse H statistic, Table I shows the criteria.

Table I. H-statistic Model Panzar-Rosse Criteria

\begin{tabular}{ll}
\hline $\mathrm{H}$ stat & Competition Level \\
\hline $\mathrm{H} \leq 0$ & Monopoly or Collusive Oligopoli (Cartel) \\
$\mathrm{O}<\mathrm{H}<\mathrm{I}$ & Monopolistic Competition \\
$\mathrm{H}=\mathrm{I}$ & Perfect Competition \\
\hline
\end{tabular}

Source: Leon (2015)

Wald Test is used to test whether the amount of $\mathrm{H}$ statistics generated from the estimated model is in between two extremes of the competition level spectrum which are monopoly and perfect competition. The Wald test has null hypothesis that can be tested separately i.e whether $\beta+\gamma+\delta=0$ which means the competition is monopoly / oligopoly, or $\beta+\gamma+\delta=1$ which means the competition are perfectly competitive. Wald statistic measures how close the unrestricted estimates meet the existing restriction on the null hypothesis. If the restriction may be justified empirically, then the unrestricted estimates will approach the restriction of the null hypothesis.

Lerner Index measures banking industry competition level starts as a weighted average of individual banks' Lerner Index. Individual banks' Lerner Index show each bank's degree of competitiveness in the banking industry. Banking industry Lerner index is a weighted average of all existing banks' Lerner Index in a banking industry where each bank's loan market share as weight. 
This study follows Demirguc-Kunt and Peria (2010) where $P_{\text {it }}$ is a ratio of total bank revenue to total asset, $M C_{i t}$. is marginal cost of bank $\mathrm{i}$ in a given period $\mathrm{t}$ which is estimated by using this model:

$$
\operatorname{LnTC}=\alpha_{0}+\alpha_{1} \operatorname{Ln} Y+\frac{1}{2} \alpha_{2}(\operatorname{Ln} Y)^{2}+\sum_{j=1}^{3} \beta_{j} \operatorname{Ln} W_{j}+\sum_{j=1}^{3} \sum_{k=1}^{3} \beta_{j k} \operatorname{Ln} W_{j} \operatorname{Ln} W_{k}+\sum_{j=1} \gamma_{j} \operatorname{Ln} Y . \operatorname{Ln} W_{j}+\varepsilon
$$

TC is bank's total cost, $\mathrm{Y}$ is bank's total asset, $W_{j k} .\left(W_{1}, W_{2}, W_{3}\right)$ are employees cost, overhead cost, and cost of fund, subsequently

Boone Indicator is estimated by this model:

$$
\operatorname{Ln}\left(\pi_{i}\right)=\alpha+\beta \operatorname{Ln}\left(M C_{i}\right)+\varepsilon_{i}
$$

$\pi_{i}$ is profit of bank $\mathrm{i}, M C_{i}$ is marginal cost of bank $\mathrm{i}$.

\section{RESULTS AND DISCUSSION}

Indonesia banking industry concentration is quite high, although consistently show a declining trend. Table 2 show Indonesia banking industry concentration trend. In terms of assets, more than half of Indonesia's banking assets still controlled only by the five major banks (CR5). Indonesia banking industry consolidation after the 1998 monetary crisis had made many Indonesia small and medium banks to be insolvent, liquidated, acquired by another bank or merged. It drove a merger wave in Indonesia banking industry and domestic bank acquisition by foreign bank. A year after the crisis, 1999, total Indonesia banking asset owned by five biggest banks were even more than $70 \%$. Indonesia Banking Architecture policy which was launched by Bank Indonesia also effectively increased the assets of small banks and the medium so percentage of the Indonesian banking assets owned by the three largest banks, CR3, was declining in faster pace than CR5 was. If in 1999, Indonesia CR3 of the asset was above $60 \%$, in 2013 it had dropped to half of it which is an indication that the asset growth of the three largest banks are not as fast as the growth of industrial assets on average. Distribution of Indonesian banking assets become relatively more evenly distributed, however CR5 which is still above $50 \%$, consistently show the declining trend. Small and medium bank, which consist of more than II 0 banks, control $50 \%$ market share. Half of indonesia banking industry was controlled only by the five largest banks. 
Banking Competition Measurement...

Buddi Wibowo

Table 2. Indonesia Banking Industry Concentration 1999-20I3

\begin{tabular}{cccccccccr}
\hline Year & $\begin{array}{c}\text { CR3 } \\
\text { Asset }\end{array}$ & $\begin{array}{c}\text { CR5 } \\
\text { Asset }\end{array}$ & $\begin{array}{c}\text { HHI } \\
\text { Asset }\end{array}$ & $\begin{array}{c}\text { CR3 } \\
\text { Loan }\end{array}$ & $\begin{array}{c}\text { CR5 } \\
\text { Loan }\end{array}$ & $\begin{array}{c}\text { HHI } \\
\text { Loan }\end{array}$ & $\begin{array}{c}\text { CR3 } \\
\text { Deposit }\end{array}$ & $\begin{array}{c}\text { CR5 } \\
\text { Deposit }\end{array}$ & $\begin{array}{c}\text { HHI } \\
\text { Deposit }\end{array}$ \\
\hline 1999 & 0.613 & 0.712 & 0.158 & 0.554 & 0.637 & 0.115 & 0.571 & 0.694 & 0.132 \\
2000 & 0.488 & 0.624 & 0.113 & 0.387 & 0.508 & 0.068 & 0.501 & 0.623 & 0.108 \\
2001 & 0.497 & 0.626 & 0.111 & 0.385 & 0.474 & 0.065 & 0.504 & 0.633 & 0.110 \\
2002 & 0.485 & 0.616 & 0.104 & 0.405 & 0.518 & 0.073 & 0.491 & 0.625 & 0.104 \\
2003 & 0.469 & 0.605 & 0.096 & 0.400 & 0.518 & 0.071 & 0.474 & 0.612 & 0.095 \\
2004 & 0.443 & 0.582 & 0.086 & 0.420 & 0.560 & 0.080 & 0.464 & 0.596 & 0.090 \\
2005 & 0.400 & 0.538 & 0.075 & 0.363 & 0.501 & 0.065 & 0.417 & 0.549 & 0.079 \\
2006 & 0.377 & 0.524 & 0.068 & 0.356 & 0.494 & 0.063 & 0.398 & 0.545 & 0.073 \\
2007 & 0.388 & 0.531 & 0.070 & 0.347 & 0.489 & 0.061 & 0.411 & 0.553 & 0.076 \\
2008 & 0.375 & 0.513 & 0.067 & 0.344 & 0.489 & 0.060 & 0.402 & 0.547 & 0.074 \\
2009 & 0.395 & 0.531 & 0.070 & 0.365 & 0.509 & 0.065 & 0.421 & 0.566 & 0.078 \\
2010 & 0.392 & 0.535 & 0.073 & 0.360 & 0.510 & 0.063 & 0.410 & 0.552 & 0.070 \\
2011 & 0.390 & 0.534 & 0.071 & 0.357 & 0.495 & 0.061 & 0.403 & 0.548 & 0.065 \\
2012 & 0.388 & 0.531 & 0.070 & 0.355 & 0.490 & 0.060 & 0.398 & 0.540 & 0.060 \\
2013 & 0.385 & 0.530 & 0.068 & 0.350 & 0.485 & 0.059 & 0.395 & 0.532 & 0.058 \\
\hline
\end{tabular}

Sources: Bank Indonesia, Statistik Perbankan Indonesia

Indonesia bank loans concentration ratios (Loan CR5) are lower than the asset concentration (Asset CR5) and Deposit concentration (Deposit CR5). This is an indication that big banks' loan market were under its asset dominance in the industry. Indonesia big banks' loan disbursement were relatively less aggressive compared to medium and small banks. Competition in Indonesia credit markets was relatively less concentrated compared to competition in the deposit market that is indicated by Loan CR3 and Loan CR5 which was consistently lower than Deposit CR3 and Deposit CR5. The intermediary function of the major banks have not fully carried out optimally, collected third party funds had not been fully disbursed in the form of loant to the real sector. On contrary position, small and medium-sized banks were able to channel more loans than collected third party funds so they used outside funding sources by issuing bonds.

Indonesia banking industry's Herfindahl-Hirschman Index $(\mathrm{HHI})$ is relatively low, both in terms of assets, loans and deposit. Indonesia's HHI were consistently under 0.15 , so we can conclude Indonesian banking industry has a relatively low concentration. This is an interesting finding that show $\mathrm{HHI}$ and Concentration Ratio as measurement of industry concentration may produce a contradicting conclusion. So, even though CR3 and CR5, which shows the market share by three and five largest 
banks, were relatively high, but $\mathrm{HHI}$ is low because of the skewed distribution of banks's market share in Indonesia banking industry. Medium and small banks have almost a similar market share. This phenomenon strengthen an indication that Indonesia banks, especially medium and small banks, have specific market niche. Market niche may be in form of geographic areas, sectors or industries that each bank served or specific customers that are quite unique such as pensioners. The magnitude of Indonesia Herfindahl-Hirschman index based on loan value show a declining pattern from around 0,80 in 2004 to 0.59 level in 2013 that indicated Indonesia bank credit markets mimicked a perfect competitive market. Competition among medium-sized banks and small banks among were relatively tight because each bank almost had similar market share.

Table 3. Malaysia, Thailand and Philippines Concentration Ratio 1999-20I I

\begin{tabular}{cccc|ccc}
\hline \multicolumn{3}{c}{ CR3 Asset } & \multicolumn{3}{c}{ CR5 Asset } \\
\hline Year & Malaysia & Thailand & Philippines & Malaysia & Thailand & Philippines \\
\hline 1999 & 46.18 & 49.03 & 80.16 & 56.51 & 68.00 & 94.44 \\
2000 & 50.27 & 49.69 & 100.00 & 62.22 & 68.66 & 93.90 \\
2001 & 46.31 & 48.44 & 99.68 & 56.82 & 67.08 & 93.70 \\
2002 & 46.06 & 48.66 & 98.97 & 56.46 & 66.98 & 92.06 \\
2003 & 45.75 & 49.22 & 98.77 & 56.60 & 67.83 & 90.58 \\
2004 & 47.76 & 47.15 & 73.43 & 59.44 & 67.11 & 87.51 \\
2005 & 49.56 & 44.17 & 41.26 & 62.25 & 64.02 & 58.68 \\
2006 & 55.04 & 44.75 & 39.60 & 66.49 & 65.28 & 57.11 \\
2007 & 54.60 & 45.83 & 49.97 & 66.49 & 65.17 & 68.60 \\
2008 & 54.51 & 45.11 & 47.49 & 66.87 & 66.23 & 65.05 \\
2009 & 55.28 & 46.73 & 46.67 & 67.10 & 67.51 & 64.44 \\
2010 & 54.19 & 47.78 & 47.57 & 66.34 & 68.98 & 64.99 \\
2011 & 48.85 & 48.24 & 51.54 & 63.69 & 69.09 & 71.04 \\
Average & $\mathbf{5 0 . 3 4}$ & $\mathbf{4 7 . 2 9}$ & $\mathbf{6 7 . 3 2}$ & $\mathbf{6 2 . 1 0}$ & $\mathbf{6 7 . 0 7}$ & $\mathbf{7 7 . 0 9}$ \\
\hline
\end{tabular}

Source: World Bank

Contradictory results between the concentration ratio and HerfindahlHirschman index show an indication that fierce competition occurred among Indonesia medium and small banks. Although intra- banking industry competition intensified, medium and small bank still existed and grew steadily. This phenomenon is reflected in simultaneous decline of $\mathrm{CR}, \mathrm{CR} 5$ and $\mathrm{HHI}$. These banks have their specific market, so even they must face an intense competiton, they were able to nurture their segment and achieve a signficant growth. If we compare Indonesian banking industry concentration, measured by $\mathrm{CR} 3$ and $\mathrm{CR} 5$ of the assets, to the neighbouring countries, 
Banking Competition Measurement...

Buddi Wibowo

we may conclude that Indonesia banking industry was relatively less concentrated than neighboring countries such as Malaysia, Thailand and the Philippines as presented in Table 3.

Indonesia banking industry concentration, Asset CR3 and CR5, were far below Asset CR3 and CR5 of Malaysia, Thailand and the Philippines, means market share and dominance of major banks in Indonesia were lower compared to neighbouring countries. But it does not mean Indonesia banking industry competition level is higher compared to those three neighboring countries. We may come to this conclusion if we can compare competition level estimated through $H$ statistic of Panzar-Rosse model, Lerner Index, and Boone Indicator which are discussed in the following subsection. Indonesian banking competition level, based on $\mathrm{H}$ statistic measured by Panzar-Rosse model of competition.

$H$ statistic is the sum of estimated regression coefficients for variables AFR, PPETK and PCE, which are respectively $\beta, \gamma$, and $\delta$. H-statistic $=\beta+\gamma+\delta$. The magnitude of $\mathrm{H}$ statistics is then tested with the Wald test on the two extreme values hypothesis, whether $\mathrm{H}$ stat $=0$ which means banking competition is oligopoly or $\mathrm{H}$ stat = I which means the competition is perfectly competitive market. The Wald test are significant over null hypothesis: $\mathrm{H}$ stat $=\mathrm{I}$ every year from 1999 to 2013 , which means that the null hypothesis is rejected. We can conclude that Indonesian banking competition was never in a perfect competitive market form.

Indonesia banking competition level based on Panzar Rosse approach are presented in Table 4. Almost all the observed years have a positive $\mathrm{H}$ statistic, except in 2000 and 2002. $H$ statistic in 2000 and 2002 is negative andWald test result show the hypothesis $\mathrm{H}$ stat $=0$ can not be rejected because of not significant probability value. We come to a conclusion that banking competition in 2000 and 2002 were oligopoly competition. However, competition in 2007 through 2013 were a monopolistic competition because Wald Test showed two hypotheses $\mathrm{H}$ stat $=0$ and $\mathrm{H}$ stat $=\mathrm{I}$, both are rejected and we mat conclude $\mathrm{H}$ stat are between 0 and I. The competition is characterized by monopolistic competition that occurs in certain market segments. Every bank compete each other, but every bank tend to have a specific market segment which is the focus of its business. A bank may behave like a monopoly because of bank's dominant control over a specific market segment. 
Table 4. Indonesia Panzar Rosse H-statistic Panzar-Rosse and Banking Industry Competition

\begin{tabular}{|c|c|c|c|c|c|}
\hline & \multirow[b]{2}{*}{ H-Stat } & \multicolumn{2}{|c|}{ Wald test } & & \multirow{2}{*}{ Market Structure/Competition Type } \\
\hline & & Hypothesis & Prob & & \\
\hline & & $\mathrm{H}-\mathrm{Stat}=\mathrm{I}$ & 0.000 & $* * *$ & \\
\hline \multirow[t]{2}{*}{2000} & -0.015 & $\mathrm{H}$-Stat $=0$ & 0.333 & & Collusive Oliøonoly \\
\hline & & $\mathrm{H}-\mathrm{Stat}=\mathrm{I}$ & 0.000 & $* * *$ & Collusive Uligopoly \\
\hline \multirow[t]{2}{*}{2001} & 0.042 & $\mathrm{H}$-Stat $=0$ & 0.006 & $* * *$ & \\
\hline & & $\mathrm{H}$-Stat $=\mathrm{I}$ & 0.000 & $* * *$ & Monopolistic Competition \\
\hline \multirow[t]{2}{*}{2002} & -0.031 & $\mathrm{H}$-Stat $=0$ & 0.204 & & \\
\hline & & $\mathrm{H}-\mathrm{Stat}=\mathrm{I}$ & 0.000 & $* * *$ & Collusive Oligopoly \\
\hline \multirow[t]{2}{*}{2003} & 0.004 & $\mathrm{H}$-Stat $=0$ & 0.564 & & \\
\hline & & $\mathrm{H}$-Stat $=\mathrm{I}$ & 0.000 & $* * *$ & Collusive Oligopoly \\
\hline \multirow[t]{2}{*}{2004} & 0.021 & $\mathrm{H}$-Stat $=0$ & 0.004 & $* * *$ & Mononolistic Comnetition \\
\hline & & $\mathrm{H}-\mathrm{Stat}=\mathrm{I}$ & 0.000 & $* * *$ & Monopolistic Competition \\
\hline \multirow[t]{2}{*}{2005} & -0.010 & $\mathrm{H}$-Stat $=0$ & 0.306 & & Collucive Olianonlv \\
\hline & & $\mathrm{H}-\mathrm{Stat}=\mathrm{I}$ & 0.000 & $* * *$ & Collusive Ullgopoly \\
\hline \multirow[t]{2}{*}{2006} & 0.004 & $\mathrm{H}$-Stat $=0$ & 0.245 & & Collusive Oliononoly \\
\hline & & $\mathrm{H}$-Stat $=\mathrm{I}$ & 0.000 & $* * *$ & Collusive Cilgopoly \\
\hline \multirow[t]{2}{*}{2007} & 0.007 & $\mathrm{H}$-Stat $=0$ & 0.062 & $* *$ & Mononolistic Competition \\
\hline & & $\mathrm{H}-\mathrm{Stat}=\mathrm{I}$ & 0.000 & $* * *$ & monoponstic compecition \\
\hline \multirow[t]{2}{*}{2008} & 0.049 & $\mathrm{H}$-Stat $=0$ & 0.024 & $* *$ & Monopolistic Competition \\
\hline & & $\mathrm{H}-\mathrm{Stat}=\mathrm{I}$ & 0.000 & $* * *$ & \\
\hline \multirow[t]{2}{*}{2009} & 0.038 & $\mathrm{H}$-Stat $=0$ & 0.001 & $* *$ & Monopolistic Competition \\
\hline & & $\mathrm{H}-\mathrm{Stat}=\mathrm{I}$ & 0.000 & $* * *$ & \\
\hline \multirow[t]{2}{*}{2010} & 0,041 & $\mathrm{H}$-Stat $=0$ & 0.015 & $* *$ & Monopolistic Competition \\
\hline & & $\mathrm{H}-\mathrm{Stat}=\mathrm{I}$ & 0.000 & $* * *$ & Monopolistic Competition \\
\hline \multirow[t]{2}{*}{2011} & 0,037 & $\mathrm{H}$-Stat $=0$ & 0.018 & $* *$ & Monopolistic Competition \\
\hline & & $\mathrm{H}$-Stat $=\mathrm{I}$ & 0.000 & $* * *$ & Monopolistic Competition \\
\hline \multirow[t]{2}{*}{2012} & 0,031 & $\mathrm{H}$-Stat $=0$ & 0.012 & $* *$ & Monopolistic Competition \\
\hline & & $\mathrm{H}$-Stat $=\mathrm{I}$ & 0.000 & $* * *$ & Monopolistic Competition \\
\hline \multirow[t]{2}{*}{2013} & 0,041 & $\mathrm{H}$-Stat $=0$ & 0.011 & $* *$ & Monopolistic Competition \\
\hline & & $\mathrm{H}$-Stat $=\mathrm{I}$ & 0.000 & $* * *$ & \\
\hline
\end{tabular}

Table 4 shows competition of Indonesia banking industry based $\mathrm{H}$-statistic Panzar-Rosse during the period 1999 to 2013 (after the Wald test) were dominated by collusive oligopoly competition and monopolistic competition. In 1999, 2000, 2002, 2003, 2005, and 2006, Indonesia banking industry mimicked an oligopoly market structure. Estimated $\mathrm{H}$-statistic in those year are close to zero. 
Banking Competition Measurement...

Buddi Wibowo

Table 5. Panzar Rosse H statistics in Malaysia, Thailand, and Filipina

\begin{tabular}{cccc}
\hline & Malaysia & Thailand & Philippines \\
\hline 2010 & 0,66 & 0,67 & 0,72
\end{tabular}

Source: Global Financial Development Database, World Bank

Strict segmentation allegedly caused a monopolistic competition in Indonesian banking industry. Indonesia banks tried to look for particular market segments, and focus on serving a specific market segment so each bank may have a strong position their own market segment. A bank may dominate a certain segments and behaves like a monopoly. Banks and its customers has a quite long and loyal relation and bank competition is more directed at non-price competition. Small firms and retirees segment, is a market niche with a higher interest rate than other customer segments, few banks focus on these segment and have stronghold. A high standard of deviation of Indonesia banks' prime lending rate is a strong indication of non-price competition and segmented banking market.

Table 6. Indonesia Banks' Cost Function

\begin{tabular}{lccll}
\hline Variable & Coeficient & Estimation & t-stat & P-value \\
\hline Constant & $\alpha_{0}$ & 0,2 & 1.02 & 0.168 \\
Asset & $\alpha_{1}$ & 1.8 & 2.31 & 0.000 \\
Asset ${ }^{2}$ & $\alpha_{2}$ & 1.9 & 1.69 & 0.091 \\
Employees Expenses & $\beta_{1}$ & 1.7 & 2.53 & 0.021 \\
Overhead Cost & $\beta_{2}$ & 2.1 & 2.98 & 0.020 \\
Cost of Fund & $\beta_{3}$ & 1.8 & 2.75 & 0.024 \\
Asset x Employee Expenses & $\gamma_{1}$ & 0.2 & 2.75 & 0.023 \\
Asset x Overhead Cost & $\gamma_{2}$ & 0.3 & 3.56 & 0.027 \\
Asset x Cost of Fund & $\gamma_{3}$ & 0.4 & 2.54 & 0.021 \\
\hline R Squared & 0.872 & & & \\
F test & $197(0.000)$ & & & \\
Durbin-Watson test & 3.789 & & &
\end{tabular}

Indonesia banking industry competition level is far under the level of banking competition in neighboring countries like Malaysia, Thailand and the Philippines. Based on the World Bank's Global Financial Development Database, the level of banking competition in Malaysia, Thailand, and the Philippines were more fiercer (Table 5). This findings strengthen an indication that the concentration ratio may not reflect the 
level of banking competition because concentration ratio of the three countries, as can be seen in Table 5, are lower than Indonesia concentration ratio. This conclusion is supported by the estimated banking competition by using other measure such as the Lerner Index and Boone Indicator which will be discussed in following section. Indonesian banking competition is relatively less stringent compared to Malaysia, Thailand and the Phillipines. To obtain estimated banking competition level by using the Lerner Index and Boone Indicator, we need to estimate banks' cost function. The estimated cost function is presented in Table 6. All variables in the cost equation bank are statistically significant. Then we can estimate bank marginal cost in Table 6.

Table 7 present comparation of banking industry competition level in Indonesia, Malaysia, Thailand and the Philippines based on the Lerner Index, by estimating equation (5) and (6) above. Lerner Index estimation results confirm the Panzar-Rosse $\mathrm{H}$ statistic which has been presented, Indonesia banking industry competitions level were lower than its neighbouring countries.

Table 7. Banking Industry Competition based on Lerner Index 2000-20I I

\begin{tabular}{lcccc}
\hline Year & Indonesia & Malaysia & Thailand & Philipines \\
\hline 2000 & 0.04 & 0.38 & 0.08 & 0.01 \\
2001 & 0.12 & 0.35 & 0.15 & 0.14 \\
2002 & 0.10 & 0.36 & 0.22 & 0.20 \\
2003 & 0.13 & 0.34 & 0.31 & 0.25 \\
2004 & 0.16 & 0.33 & 0.35 & 0.21 \\
2005 & 0.24 & 0.33 & 0.34 & 0.22 \\
2006 & 0.21 & 0.31 & 0.22 & 0.23 \\
2007 & 0.19 & 0.30 & 0.19 & 0.25 \\
2008 & 0.23 & 0.30 & 0.29 & 0.17 \\
2009 & 0.21 & 0.33 & 0.34 & 0.25 \\
2010 & 0.20 & 0.33 & 0.39 & 0.31 \\
2011 & 0.25 & 0.35 & 0.40 & 0.33
\end{tabular}

Source: World Bank

The resulted regression coefficients indicated the elasticity of profit to changes in the marginal cost of bank. It is better known as Boone Indicator as a measure of banking industry competition level. Boone Indicator for Indonesia and its neighbouring countries are presented in Table 8. Boone Indicator produces a different conclusion compared to Lerner Index and Panzar Rosse H statistics. Indonesian banking 
Banking Competition Measurement...

Buddi Wibowo

competition level is litle bit tighter than Thailand and the Philippines. This difference may come from Boone Indicator weakness which assumes that bank efficiency always may be immediately transformed into a higher income. Though in the short term usually benefits from such efficiencies has not been reflected in earnings yet (Leon, 20I5).

Table 8 Banking Industry Competition based on Boone Indicator 2000-20I I

\begin{tabular}{ccccc}
\hline Year & Indonesia & Malaysia & Thailand & Philipines \\
\hline 2000 & -0.05 & -0.02 & -0.07 & NA \\
2001 & -0.06 & 0.01 & -0.09 & NA \\
2002 & -0.06 & -0.01 & -0.04 & NA \\
2003 & -0.04 & -0.01 & -0.11 & NA \\
2004 & -0.05 & -0.01 & -0.10 & -0.07 \\
2005 & -0.07 & -0.01 & -0.09 & -0.08 \\
2006 & -0.07 & -0.02 & -0.09 & -0.08 \\
2007 & -0.07 & -0.02 & -0.09 & -0.09 \\
2008 & -0.06 & -0.02 & -0.08 & -0.10 \\
2009 & -0.05 & 0.00 & -0.09 & -0.07 \\
2010 & -0.06 & -0.01 & -0.08 & -0.07 \\
2011 & -0.06 & -0.02 & -0.08 & -0.08 \\
\hline
\end{tabular}

Source: World Bank

The low level of competition among Indonesia banks is clearly reflected in higher Indonesia banks'prime lending rate compared to its neighboring countries. The average of Indonesia banks' prime lending rate in 2015 reached $10.7 \%$ for corporate loans was far higher than Malaysia banks which was only at $3.99 \%$. Nominal interest rates actually are not comparable between countries simply because the cost of funds incurred by every bank is different, it depends on the magnitude of the eac country's inflation rate. The standard deviation of Indonesian banks prime lending rate were the highest among other countries. The high standard deviation shows distribution of the prime lending rate between banks is very skewed which shows a strong indication that banking market segmentation is quite tight in Indonesia. Indonesia banks serves their specific market so they tend to have relatively strong market power and may set different lending rates for different segments. 
Table 9. Indonesia Banks' Prime Lending Rate 200I-20I I (\%)

\begin{tabular}{llll}
\hline & Corporate Loan & Retail Credit & Small Firm Loan \\
\hline Mean & 10.70 & 11.65 & 14.04 \\
Median & 10.75 & 11.65 & 13.43 \\
Standard Deviation & 2.09 & 1.92 & 4.53
\end{tabular}

Source: Financial Services Authority, 2015

Indonesia banks has the highes profitability rate among ASEAN countries, both in terms of ROA and Net Interest Margin (NIM). Indonesia banking industry efficiency level as measured by Operating Costs to Operating Income ratio, Indonesian banks are the most inefficient banking industry compared to its neighboring countries.

Table I0. Malaysia, Thailand and Philipines Prime Lending Rate 200 I-20 I I (\%)

\begin{tabular}{lccc}
\hline & Malaysia & Thailand & Philippines \\
\hline Mean & 3.99 & 6.75 & 5.35 \\
Median & 3.95 & 6.55 & 5.05 \\
Standard Deviation & 0.35 & 0.57 & 0.75
\end{tabular}

Sources: Bank Negara Malaysia, Bank of Thailand, dan Bank Central of Philippines, 20 I 5

Banking competition level and bank profibability shows an inverse relationship, but on the other hand competition did not affect significantly banks' efficiency. This empirical result are reflected in very large negative correlation coefficient between all concentration and banking competition level measurement, except for Boone Indicator, and bank profitability. Meanwhile correlation coefficient between concentration and banking competition and bank efficiency are positive but relatively low. These two contradicting phenomenon reinforce an indication of non-price competition in the Indonesian banking market which Indonesia tend to serve a specific market segment so predominantly competition was closed to monopolistic competition market. The level of competition affected profitability due to Indonesia bank were able to transform market power into a higher profit by raising its product prices without making its customers to switch to another bank that offers a lower interest rate. Banking competitive strategies were not based on price, but through other bank product features which are costly and caused lower efficiency. 
Banking Competition Measurement...

Buddi Wibowo

Table II. Banking Profitability and Efficiency 2000-20II

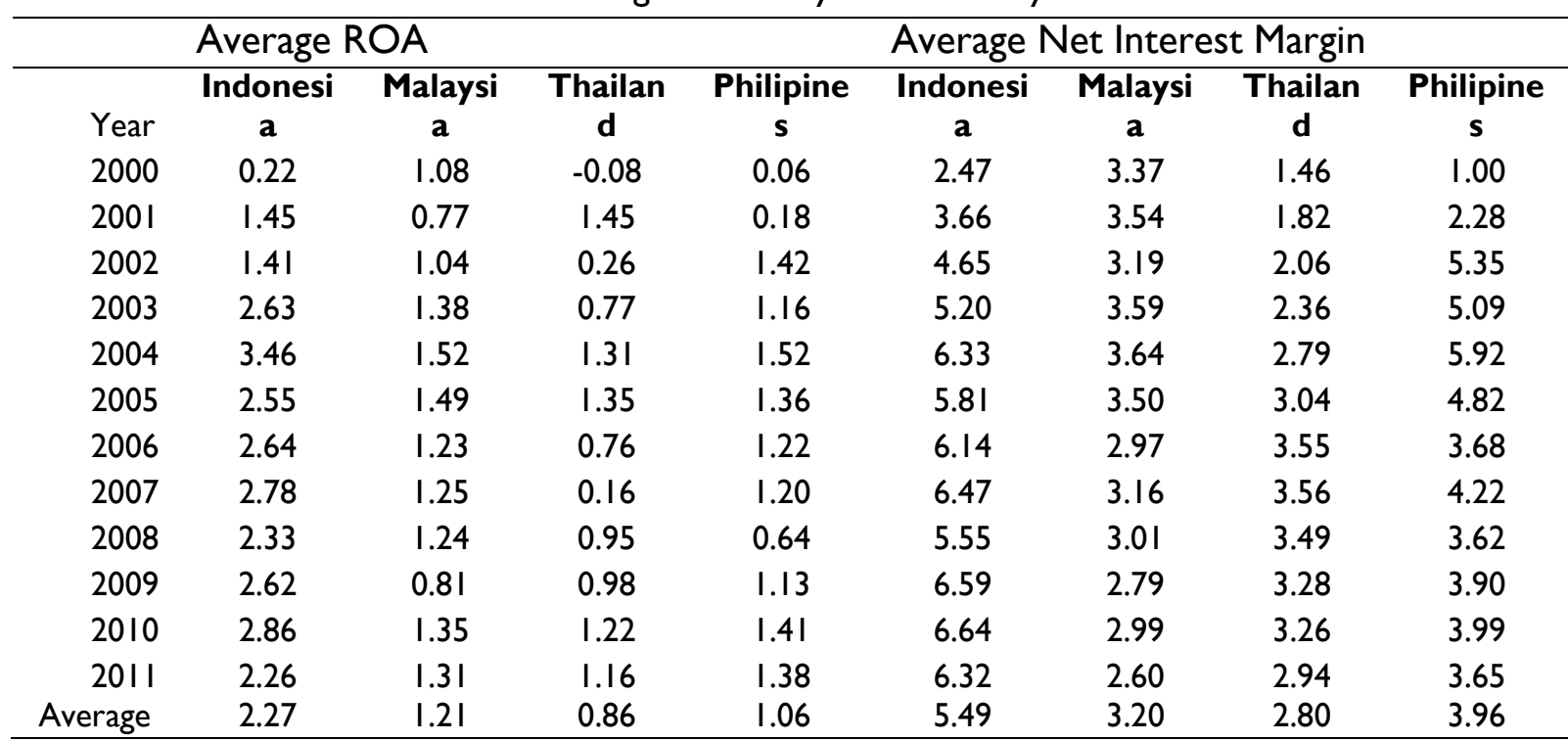

This empirical test results strengthen indications that Indonesia banking industry has an unique characteristics such as strict market segmentation based on geographic and customer behavior, non-price competition, and low financial inclusion which is reflected in lower bank credit to the GDP compared to its neighboring countries. Moreover, banks still play a dominant source of funding because Indonesia and Indonesian corporate bond market are still very small. These lagged capital market create central role of bank as a source of funding and gives Indonesia bank a very strong market power.

Table 12. Average Operating Cost to Operating Income

\begin{tabular}{rcccc}
\hline \multicolumn{5}{c}{ Average Operating Cost to Operating } \\
\hline Year & Indonesia & Malaysia & Thailand & Philipines \\
2000 & 98.64 & 39.23 & 89.96 & 86.04 \\
2001 & 95.41 & 43.60 & 75.47 & 93.70 \\
2002 & 95.77 & 39.64 & 64.93 & 59.24 \\
2003 & 88.01 & 37.70 & 55.76 & 59.36 \\
2004 & 76.61 & 35.75 & 50.03 & 66.66 \\
2005 & 88.97 & 35.22 & 49.89 & 64.62 \\
2006 & 86.05 & 39.98 & 55.78 & 61.72 \\
2007 & 84.15 & 40.66 & 58.28 & 64.25 \\
2008 & 88.76 & 41.06 & 52.07 & 70.69 \\
2009 & 86.62 & 51.64 & 60.03 & 68.96 \\
2010 & 85.42 & 37.42 & 43.99 & 51.13 \\
2011 & 79.12 & 41.52 & 47.40 & 59.43 \\
Average & 87.79 & 40.28 & 58.63 & 67.15 \\
\hline
\end{tabular}


The results support Berger, et al. (2004); Claessens and Laeven (2004) that argue concentration ratio may produce wrong indication of industry competition level. The concentration ratio can not capture banking industry competition in Indonesia and the ASEAN countries. These findings may conclude that industry concentration measures are not an appropriate proxy for competition level.

Banking competition levels are also mutually confirming in four observed ASEAN countries, in particular between Lerner Index and H Statistic Panzar Rosse. Boone Indicator generates a slightly different conclusion compared to the Lerner Index and $\mathrm{H}$ statistic Panzar Rosse. However, Boone Indicator of these ASEAN countries were only different in slightly absolute number. This is presumably because of the character of Boone Indicator which has a basic assumption that the level of efficiency of each bank in the short term always can be transform into profit (Leon, 20I5). These finding are inline with previous studies such as Tabak et al., (20I2) and Schaeck, et.al (20I3).

Table I3. Correlation of Banking Competition, Profitability, and Efficiency 2000-20 I I ROA

\begin{tabular}{lcccc}
\hline \multicolumn{1}{c}{ Competition } & Indonesia & Malaysia & Thailand & Philipines \\
\hline Lerner Index & -0.78 & 1.08 & -0.91 & -0.84 \\
H stat Panzar-Rosse & -0.84 & 0.77 & -0.93 & -0.88 \\
Boone Indicator & -0.37 & -0.25 & -0.21 & -0.16 \\
\hline
\end{tabular}

\begin{tabular}{lcccc}
\hline \multicolumn{5}{c}{ Net Interest Margin } \\
\hline \multicolumn{1}{c}{ Competition } & Indonesia & Malaysia & Thailand & Philipines \\
\hline Lerner Index & -0.84 & -0.78 & -0.85 & -0.91 \\
H stat Panzar-Rosse & 3.66 & 3.54 & -0.89 & -0.87 \\
Boone Indicator & -0.39 & -0.42 & -0.26 & -0.34 \\
\hline \multicolumn{1}{c}{ Competition } & Operating Cost to Operating Income & \\
\hline Lerner Index & 0.21 & 0.15 & 0.18 & 0.17 \\
H stat Panzar-Rosse & 0.23 & 0.17 & 0.14 & 0.12 \\
Boone Indicator & 0.41 & 0.32 & 0.21 & 0.21 \\
\hline
\end{tabular}

The empirical test results strengthen indications that Indonesia banking industry has an unique characteristics such as strict market segmentation based on geographic 
Banking Competition Measurement...

Buddi Wibowo

and customer behavior, non-price competition, and low financial inclusion. This result support Bikker and Spierdijk (2008) that argue banking industry ussually is a monopolistic market so each bank develop its market segment and create loyalty and emotional bonding with their customers. Small banks with loyal customer can survive amid tigth competition and government persuassion to merge with other small banks. It may cause Indonesia banking industry consist of many small banks compared to its neighbouring countries.

Table I4. Bank Loans to GDP 2000-2012

\begin{tabular}{ccccc}
\hline Year & Indonesia & Malaysia & Thailand & Philipines \\
\hline 2000 & 17.63 & 122.80 & 116.63 & 35.05 \\
2001 & 17.19 & 127.66 & 101.21 & 33.68 \\
2002 & 17.90 & 119.58 & 97.20 & 30.90 \\
2003 & 19.24 & 115.15 & 97.67 & 28.85 \\
2004 & 21.54 & 108.34 & 97.33 & 26.97 \\
2005 & 22.67 & 101.84 & 97.71 & 25.18 \\
2006 & 22.54 & 100.69 & 93.93 & 23.44 \\
2007 & 22.68 & 96.98 & 89.55 & 22.44 \\
2008 & 23.41 & 93.76 & 93.14 & 25.22 \\
2009 & 23.94 & 107.59 & 95.91 & 28.65 \\
2010 & 23.74 & 105.06 & 92.17 & 27.79 \\
2011 & 25.35 & 106.40 & 101.91 & 29.79 \\
2012 & 26.38 & 107.80 & 102.56 & 30.27 \\
\hline
\end{tabular}

Source: World Bank

The empirical result may conclude that Indonesia banking competition level and bank profibability shows an inverse relationship, but on the other hand competition did not affect significantly banks' efficiency. Low competition level drive bank managers to enjoy what is called by Dietrich and Wanzenreid (20II) as a "quiet life" where operational cost is not adequately controlled and efficiency levels are low and profitability remains at high level. As Berger and Hannan (1998) findings, these phenomenon are ussually found among big banks and foreign banks which fail to optimize their potential capacity. 
Tabel I5. Financial Industry Comparation 200 I-20 I I

Stock Market Capitalization to GDP Outstanding domestic private debt

(\%)

securities to GDP (\%)

\begin{tabular}{lcrrccccc}
\hline Year & \multicolumn{2}{c}{ Indonesia Malaysia } & Thailand & Philippines & Indonesia & Malaysia & Thailand & Philippines \\
\hline $200 \mathrm{I}$ & 14.00 & 127.42 & 27.45 & 41.88 & 1.23 & 35.75 & 12.10 & 0.38 \\
2002 & 14.18 & 121.36 & 33.07 & 49.30 & 1.20 & 35.63 & 12.25 & 0.47 \\
2003 & 18.38 & 132.84 & 59.26 & 36.34 & 1.73 & 35.83 & 11.22 & 0.42 \\
2004 & 24.31 & 143.80 & 75.56 & 28.27 & 2.35 & $35.6 \mathrm{I}$ & 10.48 & 0.49 \\
2005 & 25.69 & 132.49 & 69.12 & $33.7 \mathrm{I}$ & 2.23 & 47.42 & 10.43 & $0.7 \mathrm{I}$ \\
2006 & 30.68 & 130.22 & 66.70 & 45.75 & 2.03 & 61.32 & 11.13 & 1.00 \\
2007 & $40.5 \mathrm{I}$ & 148.36 & 70.79 & 59.75 & 1.98 & $62.8 \mathrm{I}$ & 11.57 & 1.07 \\
2008 & 30.26 & 116.10 & 58.09 & 47.47 & 1.57 & 56.49 & 11.91 & 0.93 \\
2009 & 24.86 & 107.06 & 45.27 & 38.16 & 1.50 & 58.89 & 13.31 & 0.93 \\
2010 & 39.46 & 138.86 & 67.11 & 60.39 & 1.61 & 58.67 & 13.25 & 1.03 \\
2011 & 45.06 & 144.09 & 81.69 & 73.90 & 1.41 & 58.09 & 12.73 & 0.96
\end{tabular}

Source: World Bank

\section{CONCLUSION}

The concentration ratio can not capture banking industry competition in Indonesia and the ASEAN countries. Industry concentration measures (CR3, CR5 and the Herfindahl-Hirschman Index) are not an appropriate proxy for competition level. Competition is more complex to be captured by concentration ratio or market dominance by some big banks. Especially in highly monopolistic competition industry, every bank has a significant market power over their respective market segments. Every bank competed each other but the competition type was a non-price competition

Indonesia banking competition level, by using $\mathrm{H}$ statistic Panzar-Rosse and the Lerner Index as a competition measure, were a monopolistic competition types. Indonesia banking industry competition level was the lowest compared to its ASEAN neighbors. Low competition level may be indicated from the high lending rate of Indonesian banks than those in the ASEAN countries. Standard deviation of Indonesia banks' prime lending rate were the highest in the region. Higher dispersion of prime lending rate among Indonesia banks were a strong indication that Indonesia banks tend to have a high market power so they can set up very different pricing strategy for different market segment. Minimal role of corporate bond market and the stock market as a source of financing in Indonesia may drive stronger position of banking 
Banking Competition Measurement...

Buddi Wibowo

industry to transform their market power into higher profitability compared to neighboring countries.

Indication of competition monopolistic in Indonesia banking industry is reinforced by strong negative correlation between Indonesia banking competition and average profitability of banks. More intense competition encouraged banks to seek a specific market segments and to be more innovative in terms of products and services so that the portfolio of products and services created high customer loyalty. Stronger market power over their market power gave Indonesia banks a privilege to launch a premium pricing strategy, so even banking competition become tighter, almost all of banks still has recorded a relatively. Later conclusion is also reinforced by low positive correlation between the banking competition and bank efficiency. Combination of strong market power, highly segmented market, and relatively high customer loyalty made Indonesia bank to be less motivated to compete through better efficiency and lower prices. Indonesia banks' competitive strategy were close to a non price competition type.

\section{REFERENCES}

Anginer, D., Demirgüç-Kunt, A., and Zhu, M. (20I4). How Does Bank Competition Affect Systemic Stability? Journal of Financial Intermediation, Vol 23, Issue I, PP I156 .

Apergis, N. et.al. (2016). New Evidence on Assessing The Level of Competition in The European Union Banking Sector: A Panel Data Approach. International Business Review. Vol 25: 395 - 407

Barbosa, K. et.al. (20I5). Assessing Competition in The Banking Industry: A MultiProduct Approach. Journal of Banking and Finance. Vol 50: 340 - 362

Berger, A. \& T. Hannan. (1998). The Efficiency Cost of Market Power in The Banking Industry: A Test of The "Quiet Life" and Related Hypotheses. Review of Economics and Statistics. Vol 24: 345 - 358

Berger, A. et.al. (2004). Bank Concentration and Competition: An Evolution in the Making, Journal of Money, Credit and Banking Vol 35 pp 234 - 26I

Bikker, J.A. \& K. Haaf. (2000). Competition, Concentration, and Their Relationship. An Empirical Analysis of The Banking Industry, Research Series Supervision No 30. De Nedherlandsche Bank, Amsterdam 
Bikker, J \& L. Spierdijk. (2008). How Banking Competition Changed Over Time. De Nedherlandsche Bank Working Paper Vol 167: 125 - 137

Bikker, J. et.al (20I2). Assessing Competition with the Panzar-Rosse Model: The Role of Scale, Costs, and Equilibrium. The Review of Economics and Statistics. Vol. 94(4): 1025-1044.

Boone, J. (2008). A New Way to Measure Competition. The Economic Journal. Vol II8 (31): |245-|26|.

Carbó, S. et.al. (2009). Cross-Country Comparisons of Competition and Pricing Power in European Banking. Journal of International Money and Finance. vol. 28(I): II5134.

Chen, S. \& C. Liao. (20II). Are Foreign Banks More Profitable than Domestic Banks? Home and Host-Country Effects of Banking Market Structure, Governance, and Supervision. Journal of Banking \& Finance. Vol 35: 819-839.

Cihak, M. et.al. (2006). Are More Competitive Banking Systems More Stable?, IMF Working Papers Vol 06/143, International Monetary Fund

Claessens, S. \& L. Laeven. (2004). What Drives Bank Competition? Some International Evidence. Journal of Money, Credit, and Banking. Vol 36 (3): 563-583.

Collender, R. \& S. Shaffer. (2003). Local Bank Office Ownership, Deposit Control, Market Structure, and Economic Growth. Journal of Banking \& Finance. Vol. 27(I): 27-57.

Degryse, H. et.al. (2009). Microeconometrics of Banking: Methods, Applications, and Results. New York. Oxford University Press.

De Jonghe, O \& R.V. Vennet. (2008). Competition Versus Efficiency: What Drives Franchise Values in European Banking? Journal of Banking and Finance. Vol. 32(9): $1820-1835$

Delis, M.D. (2012). Bank Competition, Financial Reform, and Institutions: the Importance of Being Developed. Journal of Development Economics. Vol 97 (2): $450-465$ 
Banking Competition Measurement...

Buddi Wibowo

Demirguc-Kunt, A. \& M. Peria. (2010). A Framework for Analyzing Competition in The Banking Sector: an Application to The Case of Jordan. Policy Research Working Paper Series no 5499, The World Bank.

Dietrich, A. \& G. Wazenreid. (20II). Determinants of Bank Profitability Before and During The Crisis: Evidence From Switzerland. Journal of International Financial markets, Institutions and Money. Vol 21: 307-327.

Leon, F. (2015). Does Bank Competition Alleviate Credit Constraints in Developing Countries. Journal of Banking \& Finance. Vol (57: 130-142

Maudos, J. \& L. Solís. (20II). Deregulation, Liberalization and Consolidation of The Mexican Banking System: Effects on Competition, Journal of International Money and Finance. Vol. 30 (2): 337-353

Panzar J. \& J. Rosse. (1987). Testing for Monopoly Equilibrium. Journal of Industrial Economics. Vol 25: 443-456

Samad, A. (2008). Market Structure, Conduct and Performance: Evidence from The Bangladesh Banking Industry. Journal of Asian Economics. Vol 19 (2): 181-193

Schaeck, K. et.al. (2009). Are Competitive Banking Systems More Stable? Journal of Money, Credit, and Banking Vol 4I(4): 7II-34

Shaffer, S, (2004), Patern of Competition in Banking. Journal of Economics and Business Vol 56,pp 287-313

Tabak, B. et.al. (2012). The Relationship Between Banking Market Competition and Risk-Taking: Do Size and Capitalization Matter? Journal of Banking \& Finance. Vol 36 (I2):3366-338I. 